\title{
Characterizing the hydrogeochemistry of two low-temperature thermal systems in Central Mexico
}

\author{
Morales-Arredondo J.I. ${ }^{\mathrm{a}, *}$, Esteller-Alberich M.V. ${ }^{\mathrm{b}}$, Armienta Hernández M.A. ${ }^{\mathrm{a}}$, \\ Martínez-Florentino T.A.K. ${ }^{\mathrm{C}}$ \\ ${ }^{a}$ Universidad Nacional Autonoma de Mexico, Instituto de Geofísica, Cd. Universitaria, 04510 Mexico City, Mexico \\ ${ }^{\mathrm{b}}$ Centro Interamericano de Recursos del Agua (CIRA), Facultad de Ingeniería, Universidad Autónoma del Estado de México, Cerro Coatepec S/N, 50130 Toluca, Mexico \\ ${ }^{\mathrm{c}}$ Posgraduate Student of Centro Interamericano de Recursos del Agua, FI-UAEM, Cerro de Coatepec, CU, Toluca, Edo. de México 50130, México
}

\section{A R T I C L E I N F O}

\section{Keywords:}

Geothermalism

Springs

Groundwater

Arsenic

Fluoride

Mexico

\begin{abstract}
A B S T R A C T
Two low-temperature geothermal systems located at the Trans-Mexican Volcanic Belt with presence of fluoride and arsenic were studied with the aim to determine hydrogeochemical indicators of the toxic elements' presence, and to propose adequate geothermometers. The hydrogeological and geochemical study was carried out in Ixtapan de la Sal and Tonatico (IxS-T) and Santa Cruz de Juventino Rosas (JR), both located at the limits of the Trans-Mexican Volcanic Belt (TMVB). In these regions, low-temperature geothermal activity is present $\left(\mathrm{T}=32-47^{\circ} \mathrm{C}\right)$, and various fault and fracture systems have been identified. Several faults are active, enabling the upward flow of deep geothermal water. The geothermal waters of IxS-T manifest in the form of springs and have high $\mathrm{Na}^{+}$and $\mathrm{Cl}^{-}$concentrations, whereas those of JR are captured in wells and mainly present high $\mathrm{Na}^{+}$ and $\mathrm{HCO}_{3}{ }^{-}$concentrations. The hydrochemistry of water samples was analyzed to determine the dominant hydrogeochemical processes in both regions. These data were also useful for understanding the natural origin of the high levels of arsenic and fluoride reported in the water, which are likely due to mineral dissolution processes. The concentrations of these elements surpassed the permissible limits according to Mexican law $\left(A s_{\text {tot }}=0.025 \mathrm{mg} / \mathrm{L} ; \mathrm{F}^{-}=1.5 \mathrm{mg} / \mathrm{L}\right)$ and represent a toxicity risk for the local populations. The groundwater at JR supplies all needs of the local population, while the water at IxS-T is mainly used for recreational and health spa purposes. Increasing trends of $\mathrm{As}$ and $\mathrm{F}^{-}$in the sedimentary aquifer of IxS-T are related with the increase in TDS, $\mathrm{Cl}^{-}, \mathrm{HCO}_{3}{ }^{-}$and $\mathrm{SiO}_{2}$, while silicate alteration releasing $\mathrm{Na}$ and $\mathrm{HCO}_{3}{ }^{-}$are related with As and $\mathrm{F}^{-}$presence in the volcanic aquifer of $\mathrm{JR}$. Reservoir temperature was adequately estimated with $\mathrm{K}^{2} / \mathrm{Mg}$ and $\mathrm{Na}-\mathrm{K}-\mathrm{Ca}$ (Mg corrected) geothermometers at IxS-T, and with chalcedony and quartz geothermometers at JR.
\end{abstract}

\section{Introduction}

In Mexico, high concentrations of $\mathrm{As}_{\text {tot }}$ and $\mathrm{F}^{-}$have been reported in the groundwater of several regions (Armienta and Segovia, 2008; Betancourt-Lineares et al., 2013; Esteller et al., 2015). The presence of these elements depends on the geological environment, pattern of groundwater flow, $\mathrm{pH}$, temperature, and, in some cases, anthropogenic processes (Smedley and Kinniburgh, 2002; Peters and Blum, 2003). A hydrogeological and geochemical study was performed in two regions located at the limits of the Trans-Mexican Volcanic Belt (TMVB), Ixtapan de la Sal and Tonatico (IxS-T) and Santa Cruz de Juventino Rosas (JR) (distance between these regions is $220 \mathrm{kms}$ ) (Fig. 1a), the first one located in a sedimentary basin and the second in a volcanic environment. In both areas presence of $\mathrm{As}_{\text {tot }}$ and $\mathrm{F}^{-}$has been reported. Both regions have experienced recent volcanic activity (C. Culiacán; age
$2.10 \pm 0.24 \mathrm{Ma}$; Nevado de Toluca; age $2.6 \pm 0.2 \mathrm{Ma}$ ), have a basement of sedimentary origin that presents low-grade metamorphism, and have various intricate and complex fault and fracture systems (Ban et al., 1992; García-Palomo et al., 2002). Some of these faults are active, enabling the upward flow of deep water. Therefore, these systems can be defined as low-temperature geothermal systems (Morales-Arredondo et al., 2016a, 2016b; Rodríguez et al., 2015; Martínez-Florentino, 2015). These characteristics are common along to the TMVB, and should be important to consider when classifying the geothermal water in the entire zone. In general, the geothermal waters of IxS-T rise to the ground surface as springs, containing travertine and high concentrations of $\mathrm{Na}^{+}$and $\mathrm{Cl}^{-}$, and have a temperature of around $35^{\circ} \mathrm{C}$. The geothermal waters of JR are captured in wells, and high concentrations of mainly $\mathrm{Na}^{+}$and $\mathrm{HCO}_{3}^{-}$have been detected.

In these thermal manifestations, the concentrations of arsenic and

\footnotetext{
* Corresponding author.

E-mail address: ivanma@geofisica.unam.mx (J.I. Morales-Arredondo).
} 

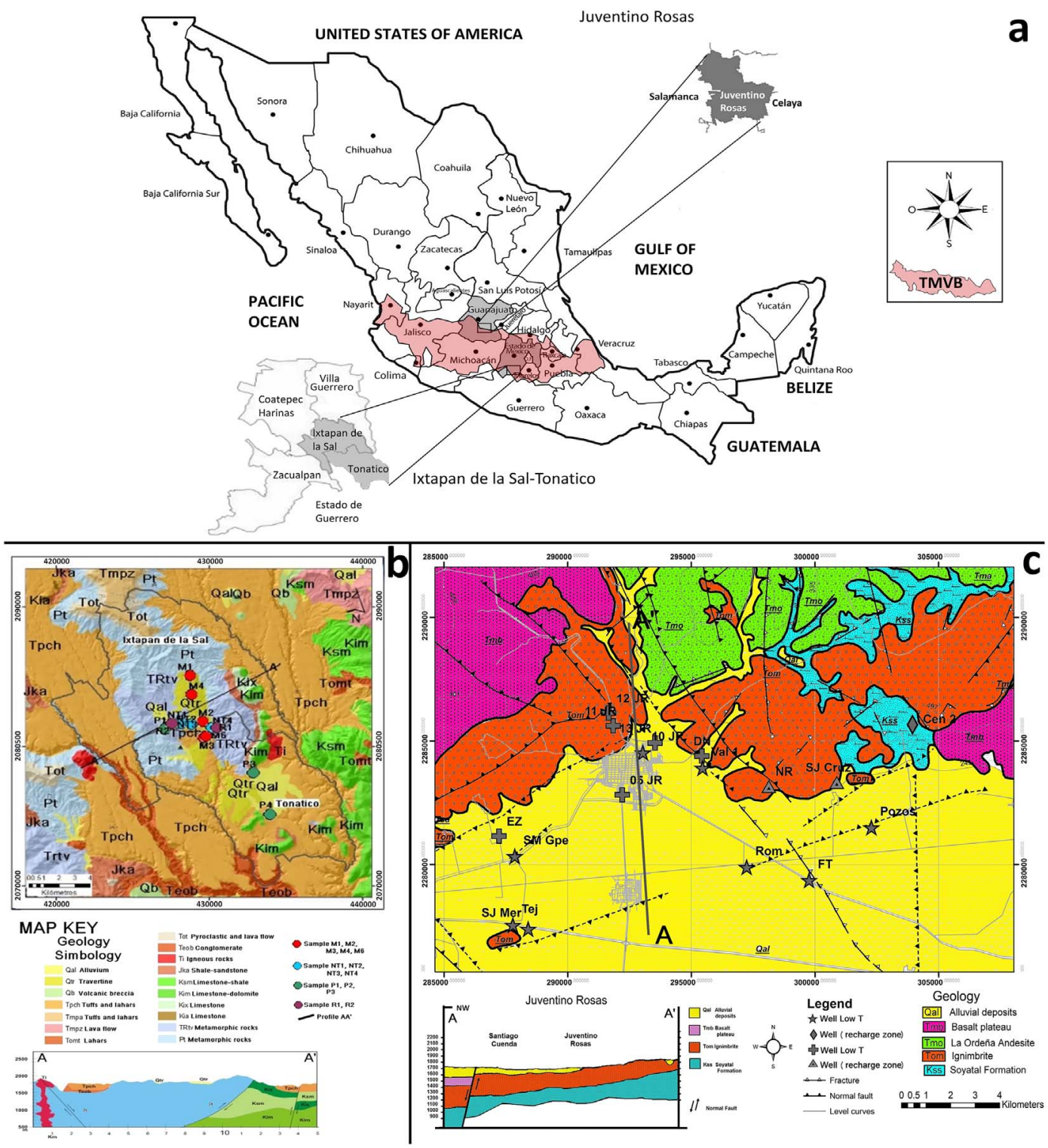

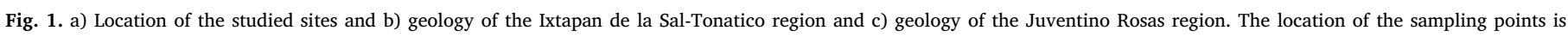
indicated.

Table 1

Hidraulic properties, geological units and fault systems located in JR and IxS-T (Morales-Arredondo et al., 2016b; Martínez-Florentino, 2015).

\begin{tabular}{|c|c|c|c|c|c|}
\hline Geological units JR & Hydraulic properties & Fault system & Geological units IxST & Hydraulic properties & Fault system \\
\hline Alluvial deposit & Unconfined aquifer & & Alluvial deposit & $5.0 \mathrm{~L} / \mathrm{s} / \mathrm{m}$ & \\
\hline $\begin{array}{l}\text { Volcano shield and monogenetic } \\
\text { volcano }\end{array}$ & $\begin{array}{l}\text { Recharge zone in some places are } \\
\text { unconfined aquifer }\end{array}$ & E-W & Travertine & $5.0 \mathrm{~L} / \mathrm{s} / \mathrm{m}$ & E-W \\
\hline Andesites from tertiary & Have secondary porosity & $\mathrm{E}-\mathrm{W}$ & $\begin{array}{l}\text { Volcanic breccia, tuffs, lahars, } \\
\text { pyroclastic and lava flows }\end{array}$ & $\begin{array}{l}\text { Between } 1.2 \text { and } \\
0.05 \mathrm{~L} / \mathrm{s} / \mathrm{m}\end{array}$ & $\begin{array}{l}\text { E-W and NE- } \\
\text { SW }\end{array}$ \\
\hline Rhyolitic domes & $\begin{array}{l}\text { In some place act as recharge zone, low } \\
\text { permeability }\end{array}$ & $\mathrm{E}-\mathrm{W}$ & Conglomerate & 0.05 to $1.0 \mathrm{~L} / \mathrm{s} / \mathrm{m}$ & \\
\hline Basaltic plateau tertiary & Recharge zone & $\mathrm{E}-\mathrm{W}$ & Igneous rocks & $\begin{array}{l}5.0 \mathrm{~L} / \mathrm{s} / \mathrm{m} \\
1.0 \text { to } 2.0 \mathrm{~L} / \mathrm{s} / \mathrm{m} \\
0.05 \text { to } 1.0 \mathrm{~L} / \mathrm{s} / \mathrm{m} \\
<0.05 \mathrm{~L} / \mathrm{s} / \mathrm{m}\end{array}$ & $\begin{array}{l}\text { E-W and NE- } \\
\text { SW }\end{array}$ \\
\hline ALLENDE andesite & $1.6 \times 10-4 \mathrm{~m}^{2} / \mathrm{s}$ & $\begin{array}{l}\text { NE-SW and } \\
\text { NWSE }\end{array}$ & Shale-sandstone & $\begin{array}{l}<0.05 \mathrm{~L} / \mathrm{s} / \mathrm{m} \\
\ll 0.05 \mathrm{~L} / \mathrm{s} / \mathrm{m}\end{array}$ & NW-SE \\
\hline CHICHINDARO rhyolite & Unknown properties, secondary porosity & $\begin{array}{l}\text { NE-SW and } \\
\text { NWSE }\end{array}$ & Limestone-shale & $\ll 0.05 \mathrm{~L} / \mathrm{s} / \mathrm{m}$ & NW-SE \\
\hline $\begin{array}{l}\text { Ignimbritic sequence from } \\
\text { Oligocene-Miocene }\end{array}$ & $\begin{array}{l}\text { Low permeability, aquitard, in some } \\
\text { circumstances act as basement }\end{array}$ & $\begin{array}{l}\text { NE-SW and } \\
\text { NWSE }\end{array}$ & Limestone-dolomite & $\ll 0.05 \mathrm{~L} / \mathrm{s} / \mathrm{m}$ & NW-SE \\
\hline SOYATAL Formation & $1.2 \times 10-4 \mathrm{~m}^{2} / \mathrm{s}$ & & $\begin{array}{l}\text { Limestone } \\
\text { Metamorphic rocks }\end{array}$ & $\begin{array}{l}\ll 0.05 \mathrm{~L} / \mathrm{s} / \mathrm{m} \\
\ll 0.05 \mathrm{~L} / \mathrm{s} / \mathrm{m}\end{array}$ & $\begin{array}{l}\text { NW-SE } \\
\text { NW-SE }\end{array}$ \\
\hline
\end{tabular}


fluoride surpass the permissible limits for water for human use and consumption established by Mexican regulations (NOM-127-SSA-1994; modified in 2000; As $=0.025 \mathrm{mg} / \mathrm{L} ; \mathrm{F}^{-}=1.5 \mathrm{mg} / \mathrm{L}$ ), thereby representing a toxicity risk and possibly causing health problems for the local populations. Groundwater at JR is used to supply all water needs of the local population, while the water at IxS-T is mainly used for recreational and balneological purposes.

This investigation had the objective of assessing the hydrogeochemical properties of two low-temperature geothermal systems located along the TMVB, the presence, origin, behavior and hydrogeochemical indicators of As and $\mathrm{F}^{-}$in each area, and to identify the most representative geothermometer for each geological setting.

\section{Location and geology}

The municipalities of Ixtapan de la Sal and Tonatico (IxS-T) are located in the State of Mexico. Physiographically, this region is located between the lower limit of the Trans-Mexican Volcanic Belt and the Sierra Madre del Sur (Fig. 1b). The climate is semi-warm subhumid with an average annual temperature between 18 and $24^{\circ} \mathrm{C}$ and a summer and winter rainfall pattern. This area forms part of the Morelos-Guerrero Watershed and presents a high structural complexity resulting from three juxtaposed tectonic domains, of which the TeloloapaIxtapan Complex dating to the Mesozoic Era is the most representative (Table 1). This complex is formed of Mesozoic sedimentary platform rocks and volcanic-sedimentary rocks of marginal-sea volcanic island arc type (Campa, 1978). In addition, this volcanic-sedimentary complex presents low-grade metamorphism and green shale facies (MartínezFlorentino, 2015). A deformed and folded series of Cretaceous Flyschtype carbonate and clastic rocks is overlain over the prior complex in a discordant manner, forming the high sierras of the zone. The third element overlapping the others is a volcanic complex composed of rhyolite and pyroclastic rocks and lahars (Table 1). The Nevado de Toluca volcano is located to the north, and basaltic plateaus ranging from 2700 to 2900 masl in elevation are positioned to the south. In some places from IxS-T existed salt deposits before prehispanic age, these deposits are not exploited (Reyes Reyes, 1998).

The municipality of Juventino Rosas (JR) is located in the state of Guanajuato and belongs to the hydrogeological province of Valle de Celaya (Fig. 1c). This study area is found between the physiographic regions of the Trans-Mexican Volcanic Belt and the Central Plateau. Lithologically, the area is formed by a sedimentary basin that overlays volcanic emissions of basic composition from the Pliocene-Pleistocene Era as well as acidic volcanic emissions from the early Oligocene to the late Mesozoic Eras. The basement is composed of sedimentary rocks with low-grade metamorphism (Morales-Arredondo et al., 2016a, 2016b; Rodríguez et al., 2016). In the north, the Sierra de Guanajuato, which is mainly composed of rhyolite-ignimbrite rocks, is found (Table 1). To the south, monogenetic volcanoes belonging to the Michoacán-Guanajuato Field are present, and this region also forms part of the Trans-Mexican Volcanic Belt. The groundwater of JR is influenced by a geological environment containing volcanic rocks of both acidic and basic composition and by a sedimentary basin filled with sediments of lacustrine-alluvial origin (Morales-Arredondo et al., 2016a, 2016b).

\section{Methodology}

Groundwater was sampled in JR in 2013 and 2014 from thermal springs, non-thermal springs, and wells in IxS-T in 2014 and 2015. The most representative results are shown in Tables 2 and 3. The water sampling and chemical analyses were performed according to international standards (APHA-AWWA-WFPC, 2005). In the wells in JR, temperature, $\mathrm{pH}$, and electric conductivity were measured in situ using a Conductronic PC 18 portable meter calibrated at each site. In IxS-T, an OrionStar A329 multiparametric meter, also calibrated at each site, was used to determine temperature, $\mathrm{pH}$, and electric conductivity.
Alkalinity was also analyzed in situ. The chemical determinations of JR samples were performed in the Laboratorio de Química Analítica of the Instituto de Geofísica of the Universidad Nacional Autónoma de México (UNAM). In this analysis, the major ions were determined. Chromium was measured by flame atomic absorption spectrophotometry, arsenic by hydride generation, boron by colorimetry and its reactions with carminic acid, fluorides by potentiometry with a selective electrode, lithium by nitrous oxide-acetylene flame emission spectrometry, and silicon by nitrous oxide-acetylene flame atomic absorption spectrometry, using a Perkin Elmer AAnalyst 100 spectrometer. UV-visible light spectroscopy, according to the molybdosilicic acid method, was used for samples with lower concentrations (up to $10 \mathrm{mg} / \mathrm{L}$ of $\mathrm{Si}$ ). The concentration of silica was determined by calculating its stoichiometric ratio to silicon.

The chemical analysis of the samples from IxS-T was carried out in the Laboratorio de Geoquímica Ambiental, Campus Juriquilla, UNAM. In this analysis, the cations were determined by inductively coupled plasma optical emission spectrometry (ICP-OES), and the concentrations $\mathrm{As}, \mathrm{B}, \mathrm{Li}, \mathrm{Si}, \mathrm{Mg}, \mathrm{Ca}, \mathrm{Na}$, and $\mathrm{K}$. The determination of anions was performed in the Laboratorio de Calidad del Agua of the Centro Interamericano de Recursos de Agua (CIRA) of the Universidad Autónoma del Estado de México (UAEMex). Sulfate was determined using the turbidimetric method and chloride through silver nitrate titration (APHA-AWWA-WFPC, 2005); fluoride was quantified with a selective electrode potentiometer. The concentration of silica was determined by calculating its stoichiometric ratio to silicon.

\section{Results and discussion}

The water samples from both JR and IxS-T had a nearly neutral $\mathrm{pH}$. In IxS-T, the temperature of thermal water was around $35^{\circ} \mathrm{C}$, while that of non-thermal springs and wells ranged from 20 to $26^{\circ} \mathrm{C}$. The most abundant ions by mass were $\mathrm{Cl}^{-}$and $\mathrm{Na}^{+}$, with the exception of well water, in which the dominant ions were $\mathrm{Ca}^{2+}$ and $\mathrm{HCO}_{3}{ }^{-}$(Table 2). In $\mathrm{JR}$, the temperature of water captured in wells ranged from 28 to $48^{\circ} \mathrm{C}$, and the most abundant ions were $\mathrm{Na}^{+}, \mathrm{Ca}^{2+}$, and $\mathrm{HCO}_{3}{ }^{-}$(Table 3).

\section{Piper diagram}

In IxS-T, based on the results of the Piper diagram, the samples of well water (IxS-T W) can be categorized as $\mathrm{Ca}-\mathrm{Mg}-\mathrm{HCO}_{3}$ type. The samples of non-thermal springs (IxS-T S) can be characterized as Ca-Na$\mathrm{HCO}_{3}-\mathrm{Cl}$ type and those of thermal springs (IxS-T HS) as Na-Ca-Cl type (Fig. 2). In JR, the samples from thermal wells can be characterized as $\mathrm{Na}-\mathrm{HCO}_{3}$ and Na-Ca- $\mathrm{HCO}_{3}$ type (JR) and those from non-thermal wells (JR Low T) as Ca-Mg-Na- $-\mathrm{HCO}_{3}$ and $\mathrm{Ca}-\mathrm{Mg}-\mathrm{HCO}_{3}-\mathrm{SO}_{4}$ type (Fig. 2). These results confirm that the water sampled in IxS-T, considering thermal spring, non-thermal spring, and well water samples, are originated from different geochemical processes in the same geological environment.

Also, the hydrogeochemical evolution of the water sampled in IxS-T from non-thermal springs evidences mixing processes, as specific chemical species of water proceeding from thermal springs and well water could be identified (Fig. 2) (Larsen et al., 2001), as explained below. In the JR region, a mixing process also appears to occur, likely indicating that deep geothermal water flows upward through the local fault system and then mixes with shallow water.

\section{Behavior of the main constituents}

The behavior of the major constituents of water samples from IxST and JR, according to the relations between ions, was determined in order to assess the influence of the geological environment on the hydrochemical variability of sampled water (Fig. 3). In IxS-T samples, the $\mathrm{Na}^{+} \mathrm{vs} \mathrm{Cl}^{-}$relationship presented a linear tendency similar to that of the halite dissolution line, as observed in Fig. 3a (Hanor, 1994; 
Table 2

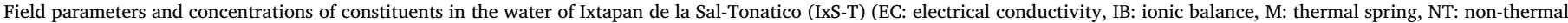
spring).

\begin{tabular}{|c|c|c|c|c|c|c|c|c|c|c|c|c|c|c|c|c|}
\hline \multirow[t]{2}{*}{ ID } & \multirow{2}{*}{$\frac{\text { Temp }}{{ }^{\circ} \mathrm{C}}$} & \multirow[t]{2}{*}{$\mathrm{pH}$} & \multirow{2}{*}{$\begin{array}{l}\mathrm{EC} \\
\mathrm{S} / \mathrm{cm}\end{array}$} & \multirow[t]{2}{*}{$\mathrm{Ca}^{2+}$} & \multirow[t]{2}{*}{$\mathrm{Mg}^{2+}$} & \multirow[t]{2}{*}{$\mathrm{Na}^{+}$} & \multirow[t]{2}{*}{$\mathrm{K}^{+}$} & \multirow[t]{2}{*}{$\mathrm{Cl}^{-}$} & \multirow{2}{*}{$\frac{\mathrm{SO}_{4}^{2-}}{\mathrm{mg} / \mathrm{L}}$} & \multirow[t]{2}{*}{$\mathrm{HCO}_{3}^{-}$} & \multirow[t]{2}{*}{ As } & \multirow[t]{2}{*}{ B } & \multirow[t]{2}{*}{$\mathrm{Li}$} & \multirow[t]{2}{*}{$\mathrm{SiO}_{2}$} & \multirow[t]{2}{*}{$\mathrm{F}^{-}$} & \multirow{2}{*}{$\begin{array}{l}\text { IB } \\
\%\end{array}$} \\
\hline & & & & & & & & & & & & & & & & \\
\hline M1 & 25.7 & 6.2 & 10,550 & 622 & 89.9 & 1328 & 160.3 & 2271.2 & 904.8 & 1126.7 & 0.30 & 22.8 & 8.1 & 26.8 & 1.60 & -0.9 \\
\hline M2 & 33.1 & 6.6 & 10,810 & 675 & 96.0 & 1463 & 144.6 & 2232.3 & 814.4 & 1107.6 & 0.64 & 23.2 & 6.9 & 26.7 & 1.62 & 4.7 \\
\hline M3 & 35.6 & 6.3 & 10,190 & 621 & 89.0 & 1348 & 136.6 & 2070.6 & 739.9 & 1110.2 & 1.66 & 22.6 & 7.1 & 25.9 & 1.61 & 3.9 \\
\hline M4 & 34.3 & 6.2 & 12,930 & 646 & 97.4 & 1343 & 137.6 & 2319.6 & 918.4 & 1533.0 & 1.53 & 23.6 & 7.7 & 26.4 & 1.64 & 0.8 \\
\hline M6 & 36.6 & 6.4 & 10,630 & 687 & 91.1 & 1557 & 151.0 & 2404.0 & 887.2 & 1118.3 & 1.74 & 23.2 & 6.9 & 27.3 & 1.51 & 3.6 \\
\hline NT1 & 22.6 & 6.8 & 1710 & 202 & 17.5 & 192 & 25.6 & 277.7 & 124.9 & 437.4 & 0.22 & 3.4 & 1.9 & 26.6 & 0.69 & 4.8 \\
\hline NT2 & 22.3 & 6.7 & 1772 & 186 & 17.5 & 188 & 28.6 & 292.6 & 124.9 & 395.3 & 0.21 & 3.4 & 1.6 & 23.5 & 0.71 & 4.7 \\
\hline NT3 & 23.1 & 6.8 & 1320 & 159 & 13.1 & 125 & 21.1 & 159.0 & 92.4 & 426.6 & 0.3 & 2.2 & 1.0 & 22.8 & 0.94 & 3.5 \\
\hline NT4 & 20.5 & 7.2 & 1723 & 148 & 20.6 & 249 & 37.7 & 301.2 & 207.1 & 352.2 & 0.29 & 3.8 & 2.1 & 25.4 & 0.73 & 3.6 \\
\hline Well P1 & 21.0 & 7 & 528 & 78 & 25.7 & 19 & 2.0 & 15.5 & 37.2 & 309.4 & 0.006 & 0.1 & 0.0 & 26.4 & 0.74 & 2.3 \\
\hline Well P3 & 21.8 & 7.3 & 476 & 70 & 22.8 & 21 & 1.6 & 12.6 & 16.1 & 272.9 & 0.006 & 0.0 & 0.0 & 34.1 & 0.35 & 2.1 \\
\hline Well P4 & 26.2 & 7.3 & 470 & 80 & 26.3 & 18 & 1.4 & 13.1 & 22.0 & 246.8 & 0.006 & 0.1 & 0.1 & 29.1 & 0.61 & 3.8 \\
\hline
\end{tabular}

Carpenter, 1978). In Fig. 3b, almost all samples are located below the gypsum dissolution line, indicating that the concentration of $\mathrm{Ca}^{2+}$ is slightly lower than that of $\mathrm{SO}_{4}{ }^{2-}$, which may be due to the dissolution of calcite. In Fig. 3c, the concentrations of $\mathrm{HCO}_{3}{ }^{-}$are higher than those of $\mathrm{SiO}_{2}$ ( $>10: 1$ ), which could result from the alteration of carbonates (Appelo and Postma, 2005; Capaccioni et al., 2005), specifically carbonate or dolomite rocks, as deduced from Fig. 3d. Based on the above, all water samples from the IxS-T region present chemical evidence suggesting that the water has passed through carbonate or sedimentary rocks, thereby promoting the dissolution of ionic species. As presented in the lithological profile of this region in Fig. 1a, a large part of the basement is composed of dolomitic carbonate rocks.

With respect to sampled well water in IxS-T, the concentrations of alkaline earth metals $\left(\mathrm{Ca}^{2+}+\mathrm{Mg}^{2+}\right)$ were higher in comparison to those of alkaline metals $\left(\mathrm{Na}^{+}+\mathrm{K}^{+}\right)$, as shown in Fig. 3f. In addition, the concentrations of bicarbonates in solution $\left(\mathrm{CO}_{3}{ }^{2-}+\mathrm{HCO}_{3}{ }^{-}\right)$exceeded those of sulfates and chlorides in solution $\left(\mathrm{SO}_{4}{ }^{2-}+\mathrm{Cl}^{-}\right)$. These are common characteristics of recently infiltrated water and correspond with those of a local flow (Tóth, 1999; Chadha, 1999). In the samples from thermal springs, the concentrations of alkaline metals $\left(\mathrm{Na}^{+}+\mathrm{K}^{+}\right)$exceeded those of alkaline earth metals $\left(\mathrm{Ca}^{2+}+\mathrm{Mg}^{2+}\right)$, while the concentrations of sulfates and chlorides in solution $\left(\mathrm{SO}_{4}{ }^{2-}+\mathrm{Cl}^{-}\right)$surpassed those of bicarbonates in solution $\left(\mathrm{CO}_{3}{ }^{2-}+\mathrm{HCO}_{3}{ }^{-}\right)$. These are common characteristics of deep water and of a system with intermediate or regional flow. The samples from nonthermal springs presented characteristics in between those of well water and thermal springs (Chadha, 1999), as observed in the Piper diagram of Fig. 2.

With respect to the water samples from JR, the concentration of $\mathrm{Na}^{+}$was greater than that of $\mathrm{Cl}^{-}$, as shown in Fig. 3a, suggesting that the presence of $\mathrm{Na}^{+}$could be due to plagioclase weathering (Appelo and Postma, 2005). The concentration of $\mathrm{Ca}^{2+}$ was greater than that of $\mathrm{SO}_{4}{ }^{2-}$. In this case, Hounslow (1995) indicates that the source of $\mathrm{Ca}^{2+}$ could be the dissolution of calcite and/or silicates (Fig. 3b), but other processes as ionic exchange, $\mathrm{pH}$ or redox conditions may regulate the water chemistry (Russak and Sivan, 2010), in JR and IxS-T pH is neutral to slightly alkaline and the environment dominantly is reducing (Morales-Arredondo et al., 2016b; Martínez-Florentino, 2015). The concentrations of $\mathrm{HCO}_{3}{ }^{-}$were superior to those of $\mathrm{SiO}_{2}$ and found in a relationship of $>3: 1$ to $<10: 1$; this phenomenon is likely due to the alteration of the silicates present in the environment (Fig. 3c) (Hounslow, 1995; D'Amore et al., 1983; Drever and Hurcomb, 1986). The hydrogeochemical evolution of water in JR could be explained by the weathering of volcanic rocks of mostly acidic composition (Fig. 3d) (Ravenscroft and McArthur, 2004), although the water could have also had contact with carbonate rocks (Figs. 2 and 3b). Furthermore, in the environment, the mixing of deep geothermal water and shallow water is evident (Figs. 2 and 3d). Another process that could be occurring is ion exchange (Fig. 3e), as the presence of $\mathrm{Ca}^{2+}$ and $\mathrm{Mg}^{2+}$ decreases while the concentrations of $\mathrm{Na}^{+}$and $\mathrm{K}^{+}$increase in the direction of relative groundwater flow. This phenomenon has been observed during the weathering of silicates and causes the subsequent formation of clays that favor ion exchange processes (Ravenscroft and McArthur, 2004; Jalali, 2005), as previously reported in JR by Morales-Arredondo et al.

Table 3

Field parameters and concentrations of constituents in the water of Juventino Rosas (JR) (EC: electrical conductivity, IB: ionic balance, n.d.: not detected).

\begin{tabular}{|c|c|c|c|c|c|c|c|c|c|c|c|c|c|c|c|c|}
\hline \multirow[t]{2}{*}{ Well } & \multirow{2}{*}{$\frac{\text { Temp }}{{ }^{\circ} \mathrm{C}}$} & \multirow[t]{2}{*}{$\mathrm{pH}$} & \multirow{2}{*}{$\frac{\text { E.C. }}{\mu S / \mathrm{cm}}$} & \multirow[t]{2}{*}{$\mathrm{Ca}^{2+}$} & \multirow[t]{2}{*}{$\mathrm{Mg}^{2+}$} & \multirow[t]{2}{*}{$\mathrm{Na}^{+}$} & \multirow[t]{2}{*}{$\mathrm{K}^{+}$} & \multirow[t]{2}{*}{$\mathrm{Cl}^{-}$} & \multirow[t]{2}{*}{$\mathrm{SO}_{4}{ }^{2-}$} & \multirow{2}{*}{$\begin{array}{c}\mathrm{HCO}_{3}{ }^{-} \\
\mathrm{mg} / \mathrm{L}\end{array}$} & \multirow[t]{2}{*}{ As } & \multirow[t]{2}{*}{ B } & \multirow[t]{2}{*}{$\mathrm{Li}$} & \multirow[t]{2}{*}{$\mathrm{SiO}_{2}$} & \multirow[t]{2}{*}{$\mathrm{F}^{-}$} & \multirow{2}{*}{$\frac{\text { IB }}{\%}$} \\
\hline & & & & & & & & & & & & & & & & \\
\hline $05 \mathrm{JR}$ & 35 & 7.3 & 751 & 35.8 & 6.1 & 90 & 8.1 & 21.5 & 38.8 & 289.9 & 0.033 & 0.50 & 0.07 & 52.5 & 2.15 & 1.7 \\
\hline $10 \mathrm{JR}$ & 36 & 6.8 & 590 & 16.2 & 1.5 & 99 & 3.7 & 6.7 & 26.8 & 286.3 & 0.045 & 0.57 & 0.09 & 35.1 & 2.93 & -0.8 \\
\hline $11 \mathrm{JR}$ & 28 & 6.9 & 629 & 44.7 & 10 & 49 & 26 & 2.6 & 8.6 & 346.7 & 0.004 & n.d. & n.d. & 82.8 & 0.77 & -0.6 \\
\hline $12 \mathrm{JR}$ & 32 & 6.7 & 660 & 43.4 & 8.4 & 63 & 11.8 & 3.9 & 12.9 & 343.0 & 0.006 & n.d. & n.d. & 51.1 & 0.57 & -1.0 \\
\hline $13 \mathrm{JR}$ & 34 & 6.6 & 594 & 32.4 & 7.8 & 67 & 9.5 & 5.2 & 23.9 & 294.7 & 0.017 & 0.50 & 0.05 & 37.1 & 2.13 & -0.6 \\
\hline D N & 35 & 6.3 & 459 & 28.7 & 7.4 & 38 & 10.8 & 3.7 & 23.1 & 218.6 & 0.007 & n.d. & n.d. & 37.6 & 0.98 & -2.6 \\
\hline E Z & 24 & 7.2 & 646 & 37.3 & 6.1 & 76 & 14.2 & 17.1 & 46.4 & 323.7 & 0.009 & n.d. & n.d. & 71.9 & 0.57 & -5.7 \\
\hline $\mathrm{F} \mathrm{T}$ & 37 & 7.3 & 595 & 19.1 & 6.5 & 84 & 6.8 & 8.4 & 26.6 & 280.2 & 0.016 & n.d. & n.d. & 52.9 & 1.07 & -0.9 \\
\hline N R & 34 & 6.4 & 473 & 33.6 & 10.4 & 32 & 11.3 & 6.2 & 32.7 & 207.8 & 0.006 & n.d. & n.d. & 25.1 & 0.98 & -0.8 \\
\hline Pozos & 48 & 7.1 & 648 & 18.1 & 3.6 & 85 & 4.8 & 6.3 & 40.3 & 280.2 & 0.046 & n.d. & n.d. & 37 & 1.65 & -5.6 \\
\hline ROM & 38 & 8.0 & 577 & 4.5 & 0.6 & 103 & 1.7 & 9.8 & 29.1 & 258.5 & 0.023 & n.d. & n.d. & 54.4 & 1.79 & -3.4 \\
\hline S J Cruz & 30 & 6.8 & 696 & 62.9 & 21.4 & 40 & 3.4 & 4.4 & 46.2 & 352.7 & 0.007 & 0.51 & 0.05 & 27.8 & 0.84 & -1.0 \\
\hline S J Mer & 47 & 7.5 & 494 & 10.8 & 2.2 & 85 & 9.4 & 9.4 & 21.8 & 257.3 & 0.023 & 0.60 & 0.05 & 65 & 3.03 & -2.8 \\
\hline S M Gpe & 30 & 7.4 & 576 & 16.4 & 1.9 & 87 & 15.9 & 9.7 & 34.0 & 265.7 & 0.017 & 0.44 & 0.06 & 61.7 & 1.37 & -1.6 \\
\hline TEJ & 42 & 7.3 & 517 & 12.4 & 2.2 & 95 & 10.4 & 11.7 & 22.9 & 270.6 & 0.023 & n.d. & n.d. & 72.2 & 2.81 & -0.3 \\
\hline VAL1 & 33 & 7.1 & 660 & 13.8 & 2.9 & 88 & 11.3 & 9.0 & 25.7 & 275.4 & 0.044 & n.d. & n.d. & 54 & 2.65 & -2.5 \\
\hline
\end{tabular}




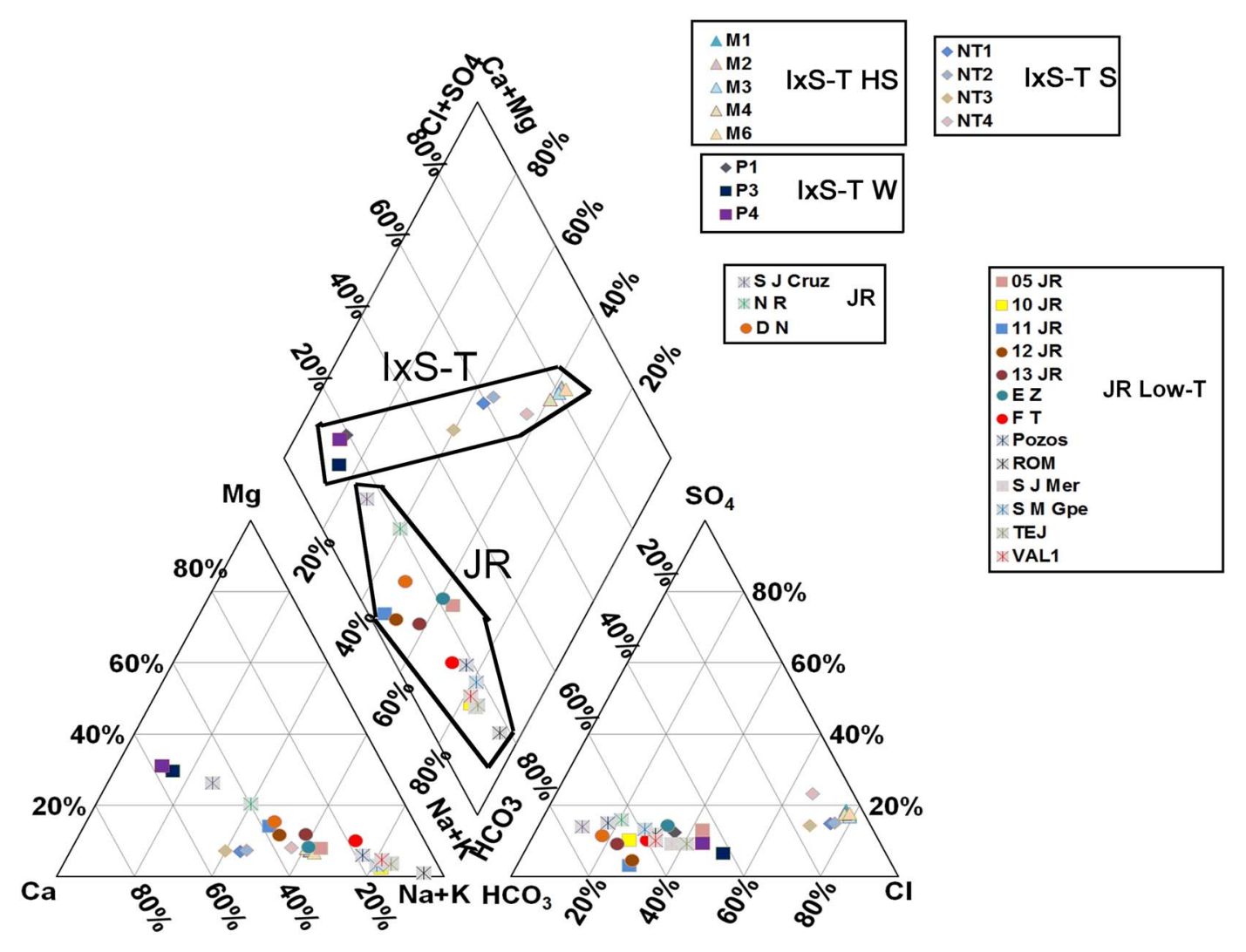

Fig. 2. Piper diagram of water samples from Ixtapan de la Sal-Tonatico (IxS-T) and Juventino Rosas (JR).

(2016a, 2016b).

\section{Geothermometry}

Based on the assumption that the concentrations of $\mathrm{Mg}^{2+}$ and $\mathrm{SO}_{4}{ }^{2-}$ present a significant decrease in high-temperature geothermal environments (Stueber and Walter, 1991), which was not observed in the water samples of IxS-T or JR, a geothermometry study was proposed to determine the temperatures of these low-temperature reservoirs.

Silica $\left(\mathrm{SiO}_{2}\right)$ geothermometers were used to calculate the minimum temperature of the water reservoirs because these are ideal for low temperatures systems with equilibrium between silica concentrations in fluid and rock (Karingithi, 2009; Fournier, 1977; Arnorsson, 1975). The concentration of silica in the water samples of JR, for instance, is governed by the chemical equilibrium with minerals such as chalcedony and quartz (Fig. 4), enabling the application of silica geothermometers. However, the water samples of IxS-T do not present equilibrium with silica minerals. This could be attributed to the distinct processes that occur in this aquifer, wherein whichever process is causing the high level of salinity is perhaps the most important. Giggenbach et al. (1983) and Giggenbach (1986) suggested that in high salinity environments, the use of $\mathrm{SiO}_{2}$ geothermometers is not ideal. Therefore, for the IxS-T region, the temperature prediction for its brackish water was performed with a $\mathrm{K}^{2} / \mathrm{Mg}$ geothermometer (Giggenbach, 1986), which shows rapid reequilibration in the water of superficial aquifers (Giggenbach et al., 1983). In comparison, the silica geothermometer shows that reequilibrium is established at a lesser velocity. In addition, a Na-K-Ca geothermometer with $\mathrm{Mg}$ correction was used to estimate the temperature and equilibrium conditions of deep aquifers (Fournier and Potter, 1979). The results suggest that IxS-T is a low-temperature geothermal system with a minimum reservoir temperature of $80^{\circ} \mathrm{C}$ and a maximum of $111^{\circ} \mathrm{C}$ but it is necessary to consider that the calculated temperatures for samples from IxS-T (NT1, NT2, NT3), with those geothermometers may not be representative due to mixing processes. On the other hand, JR is a low temperature system with a minimum reservoir temperature ranging from 40 to $99^{\circ} \mathrm{C}$ (Morales-Arredondo et al., 2016a, 2016b) (Fig. 4, Table 4).

\section{Saturation index}

Different geothermometers were applied in JR and IxS-T to calculate reservoir temperatures (Fig. 4, Table 4), however possible mixing processes may affect the estimated temperature, for this reason the multicomponent fluid-mineral equilibria at a particular temperature was determined, to compare and evaluate the results obtained with the geothermometers. Reed and Spycher (1984) consider that if a set of minerals approaches equilibrium at a specific temperature, this has a close similarity to the reservoir temperature or to the source aquifer temperature of the particular water evaluated.

To estimate the reservoir temperature a geothermometric modeling was carried out. This technique simulates the theoretical temperature increase of the sampled waters to determine the one corresponding to the saturation of the minerals present in the reservoir, or to determine an equilibrium convergence point. In this case, as a condition to make the calculations we assumed that the water chemical composition did not change with increasing temperature. All simulations were made with PHREEQC C. Quartz and chalcedony were selected to model JR since both minerals have been reported in this zone and also reported to be in equilibrium with the fluid (Morales et al., 2015). Quartz, anhydrite and celestine being minerals reported in the zone (MartínezFlorentino, 2015) were selected to model IxS-T.

Results obtained for JR indicated that water is close to equilibrium with quartz and chalcedony for all wells (Fig. 5a, b and c), and boiling leads to sharp supersaturation with respect to both minerals in a temperature range between 65 and $105{ }^{\circ} \mathrm{C}$ for chalcedony and between 85 and $115{ }^{\circ} \mathrm{C}$ for quartz. These results are similar to some of the calculated values with geothermometers (Fig. 4, Table 4). The chalcedony geothermometer and the chalcedony equilibrium modeling, both 

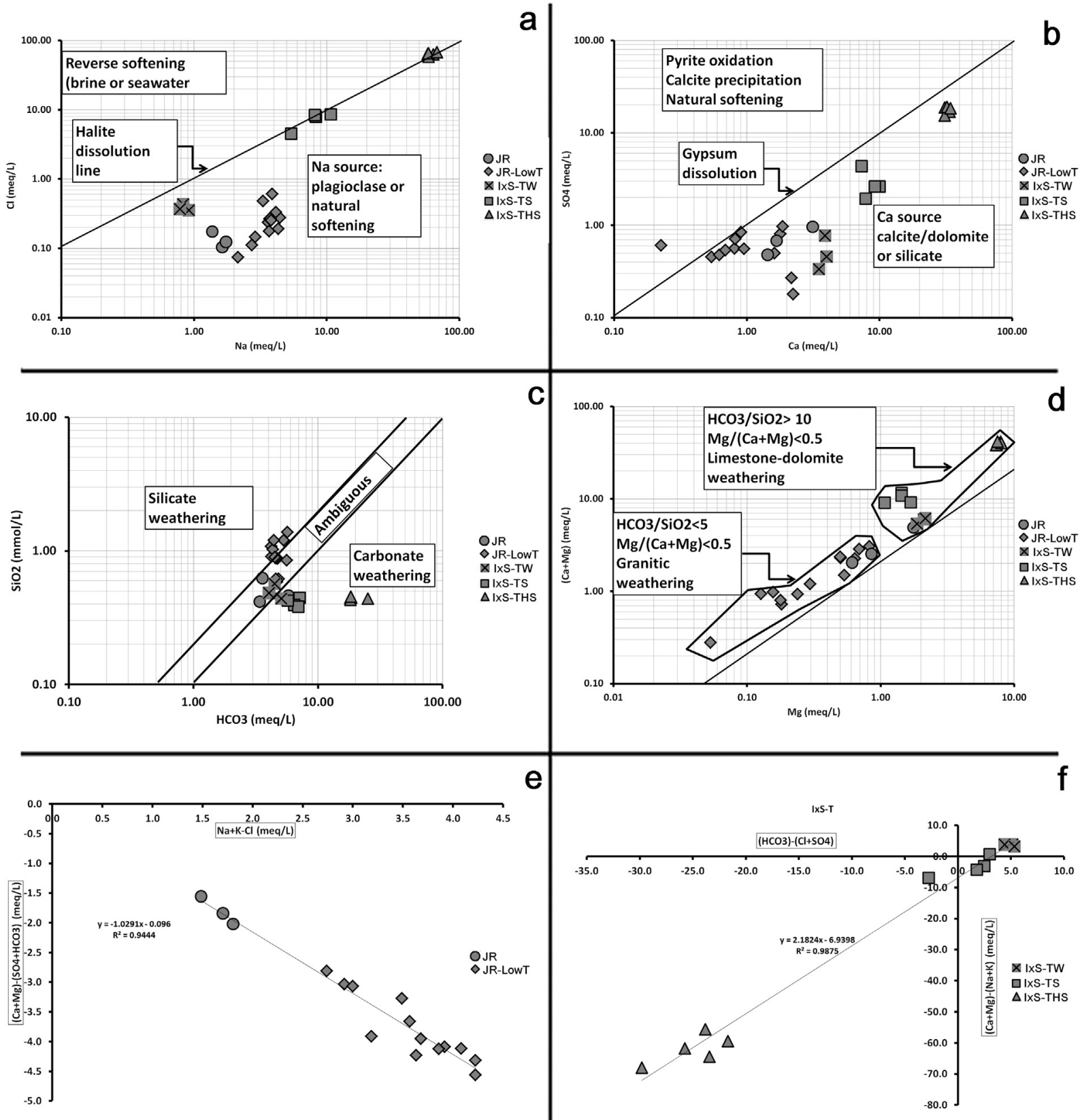

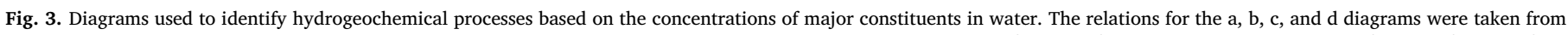

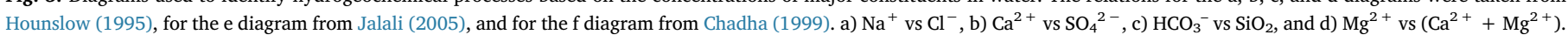

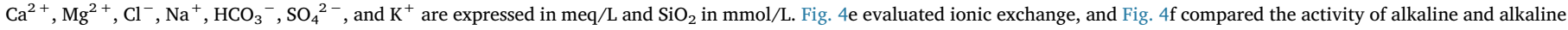
earth metals vs bicarbonates, sulfates, and chlorides in solution.

predict a lower temperature with respect to silica contents in groundwater. According to the equilibrium calculations obtained in IxS-T, anhydrite and celestine generally show over-saturation trends with increasing temperature, however, due to their different precipitation kinetics, both display a distinct temperature range to the saturation level, starting from a temperature of $93^{\circ} \mathrm{C}$ for anhydrite and $145^{\circ} \mathrm{C}$ for Celestine; quartz shows under-saturation trends at lower temperature $51{ }^{\circ} \mathrm{C}$ (Fig. 5d and e). Fig. 5e shows two temperature ranges in which the saturation states of selected minerals converge towards equilibrium, the first at $78{ }^{\circ} \mathrm{C}$ (quartz-anhydrite) and the second at $110{ }^{\circ} \mathrm{C}$ (quartzcelestine); the second is the most representative and matches with the temperature values estimated with the applied geothermometers included in Table 4.

It should be made clear that mixing, degassing/boiling and other common processes such as precipitation may affect the calculation of equilibrium temperature in reservoir of both sites and it is necessary to estimate mixing processes to calculate the reservoir temperature.

\section{Cl-B-Li ternary diagram}

To understand processes occurring in geothermal systems, $\mathrm{Li}$ is one trace element that is often included because it is not significantly affected by the secondary processes that occur during rock dissolution. Determining the proportion of $\mathrm{Li}$ also aids to evaluate the origin of $\mathrm{Cl}^{-}$ and B, which are conservative elements in geothermal water. B can be an indicator of the degree of maturity of geothermal systems: its concentration decreases with respect to that of $\mathrm{Cl}^{-}$and $\mathrm{Li}$ in old geothermal systems versus recent geothermal systems (Spivack et al., 1987; Mnjokava, 2007). Meanwhile, in deep geothermal systems, the concentration of $\mathrm{Cl}^{-}$increases with respect to $\mathrm{SO}_{4}{ }^{2-}$. This process is 


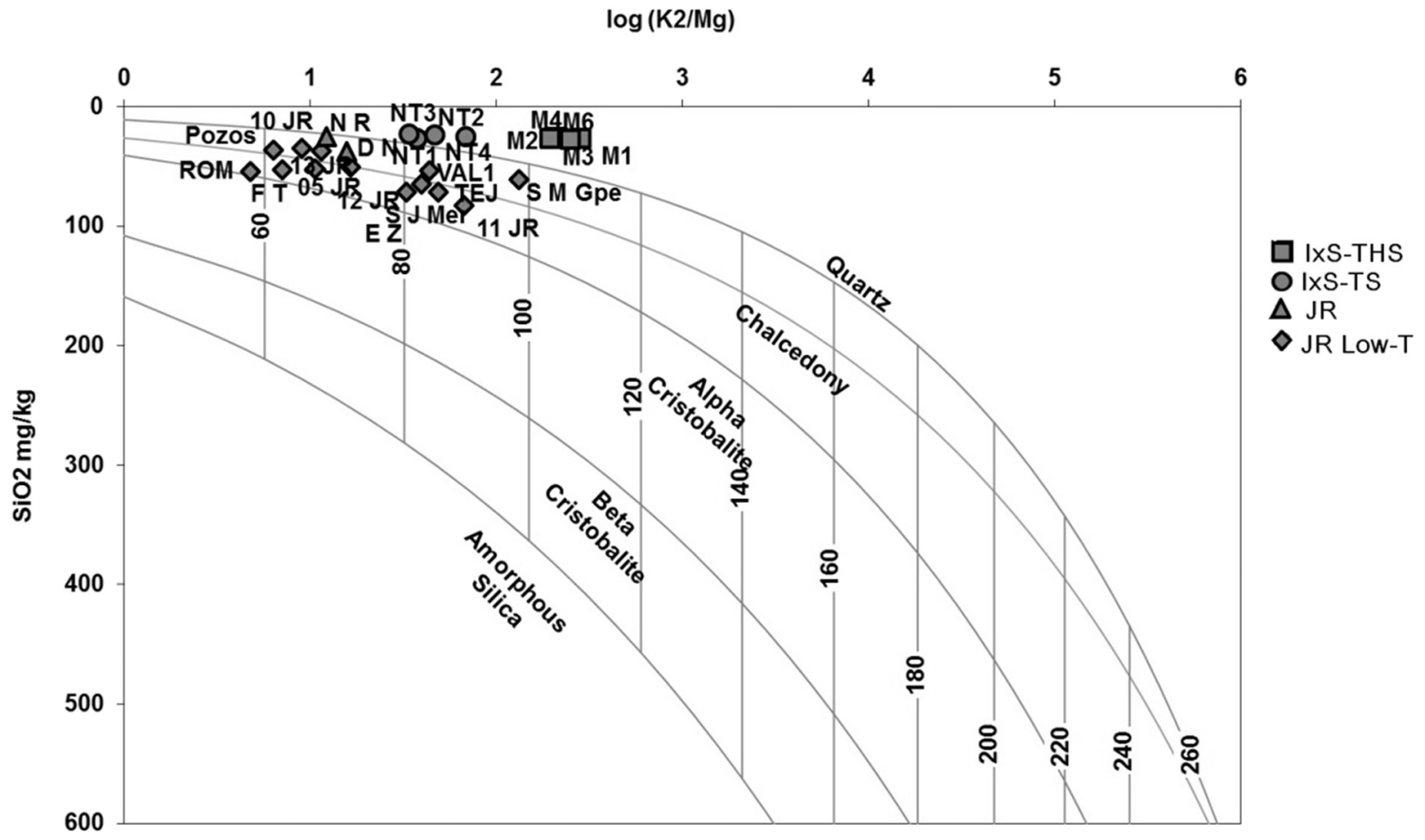

Fig. 4. Identification of the most suitable geothermometer for calculating the water reservoir temperatures of JR and IxS-T (Giggenbach and Glover, 1992).

Table 4

Minimum temperatures $\left({ }^{\circ} \mathrm{C}\right)$ of the water reservoirs of JR and IxS-T based on geothermometer calculations.

\begin{tabular}{llllll}
\hline $\begin{array}{l}\text { Sample } \\
\text { JR }\end{array}$ & Chalcedony $^{\mathrm{a}}$ & Chalcedony $^{\mathrm{b}}$ & $\begin{array}{l}\text { Sample } \\
\text { IxS-T }\end{array}$ & $\mathrm{K}^{\mathrm{b}} / \mathrm{Mg}^{\mathrm{c}}$ & $\begin{array}{l}\text { Na-K-Ca, Mg } \\
\text { correction }^{\mathrm{d}}\end{array}$ \\
\hline NR & 40.50 & 43.63 & $\mathrm{M} 1$ & 111 & 104 \\
SJ Cruz & 44.80 & 47.74 & $\mathrm{M} 2$ & 107 & 101 \\
10 JR & 54.98 & 57.30 & $\mathrm{M} 3$ & 106 & 101 \\
Pozos & 57.47 & 59.64 & M4 & 105 & 97 \\
13 JR & 57.55 & 59.72 & M6 & 109 & 105 \\
DN & 58.12 & 60.26 & NT1 & 83 & 86 \\
12 JR & 72.97 & 74.18 & NT2 & 86 & 92 \\
05 JR & 74.33 & 75.45 & NT3 & 82 & 80 \\
FT & 74.70 & 75.79 & NT4 & 91 & 105 \\
Val1 & 75.73 & 76.75 & & & \\
Rom & 76.16 & 77.15 & & & \\
SMG & 82.75 & 83.29 & & & \\
SJ Merino & 85.55 & 85.90 & & & \\
EZ & 91.10 & 91.05 & & & \\
Tej & 91.33 & 91.26 & & & \\
11 JR & 99.11 & 98.48 & & & \\
\hline
\end{tabular}

a Fournier (1977).

b Arnorsson (1975).

c Giggenbach (1986).

d Fournier and Potter (1979).

mainly influenced by the superficial oxidation of sulfide and the low solubility of sulfate minerals at high temperatures (Giggenbach, 1986; Nicholson, 1993).

The Cl-Li-B ternary diagram (Fig. 6a) is mainly utilized in hightemperature geothermal systems, as both $\mathrm{B}$ and $\mathrm{Cl}^{-}$are volatile and mobilized by vapor at high temperatures. In addition, their presence can be linked with the formation of a deep brine layer or with an increase in temperature (Spivack et al., 1987; Arnórsson and Andrésdóttir, 1995). At low temperatures and in fluids rich in $\mathrm{NaCl}, \mathrm{B}$ remains in volatile form, and the $\mathrm{Cl} / \mathrm{B}$ ratio is elevated (Magaña, 1999). In fluids derived from subducted sediments, high concentrations of B have also been found in comparison to superficial water (Peacock and Hervig, 1999). In addition, elevated contents of B have been quantified in shale and marine sediments due to the adsorption of B by clay minerals (Goldschmidt and Peters, 1932; Williams et al., 2001). Furthermore, B is highly mobile in the aqueous phase in environments of sedimentary origin (Levinson, 1980). Several of these geological characteristics were present at IxS-T and can explain the high B content in spring water. Fig. $6 \mathrm{~b}$ shows that the samples from IxS-THS have high $\mathrm{Cl}$ and $\mathrm{B}$ concentration, while samples from IxS-TW have low contents of $\mathrm{Cl}$ and $\mathrm{B}$, it is possible that concentrations of samples from IxS-TS reflect a mixture process.

Relative concentrations of $\mathrm{Cl}, \mathrm{Li}$, and $\mathrm{B}$ indicate that the geothermal system of IxS-T could have a high degree of maturity because $\mathrm{Cl}^{-}$ concentration is proportionally greater than those of $\mathrm{B}$ and Li. This could be due to the salinity of the water and the possible upward migration of deep water, (Fig. 6a), It would be necessary to perform an isotopic study of ${ }^{14} \mathrm{C},{ }^{18} \mathrm{O}$ and Deuterium to confirm or reject this theory. The concentrations of $\mathrm{Cl}^{-}$and $\mathrm{B}$ suggest that their presence is due to rock dissolution. There is no evidence of a magmatic contribution to the environment according to the comparative concentrations of $\mathrm{Cl}^{-}$and B (Fig. 6b). Water in IxS-T therefore originates from a deep environment, and its geothermal characteristics likely result from heating, wherein water is heated through its interaction with active and deep faults, and/or increasing temperatures along the geothermal gradient.

In the case of $\mathrm{JR}$, the concentrations of $\mathrm{Cl}^{-}, \mathrm{Li}$, and $\mathrm{B}$ indicate that the water comes from a recent low-temperature geothermal system (Fig. 6a). The comparison of the $\mathrm{Cl}^{-}$and $\mathrm{B}$ ratio in the water samples does not indicate a magmatic contribution of heat (Fig. 6b). Therefore, the heat source in JR may be remnant heat, or result from radioactive decay, or the interaction of the water flow with deep, active faults. Considering the characteristics of the aquifer (basin filled with sedimentary material and presence of clay), boron may be adsorbed by clay during lateral flow, and this phenomenon can affect the $\mathrm{Cl}$ and $\mathrm{B}$ concentrations if materials of sedimentary origin are present in the groundwater flow environment (Kharaka and Hanor, 2007), this effect complicates the evaluation of mixing processes using concentrations of some elements.

To confirm some of the hypotheses raised here (mainly mixing 

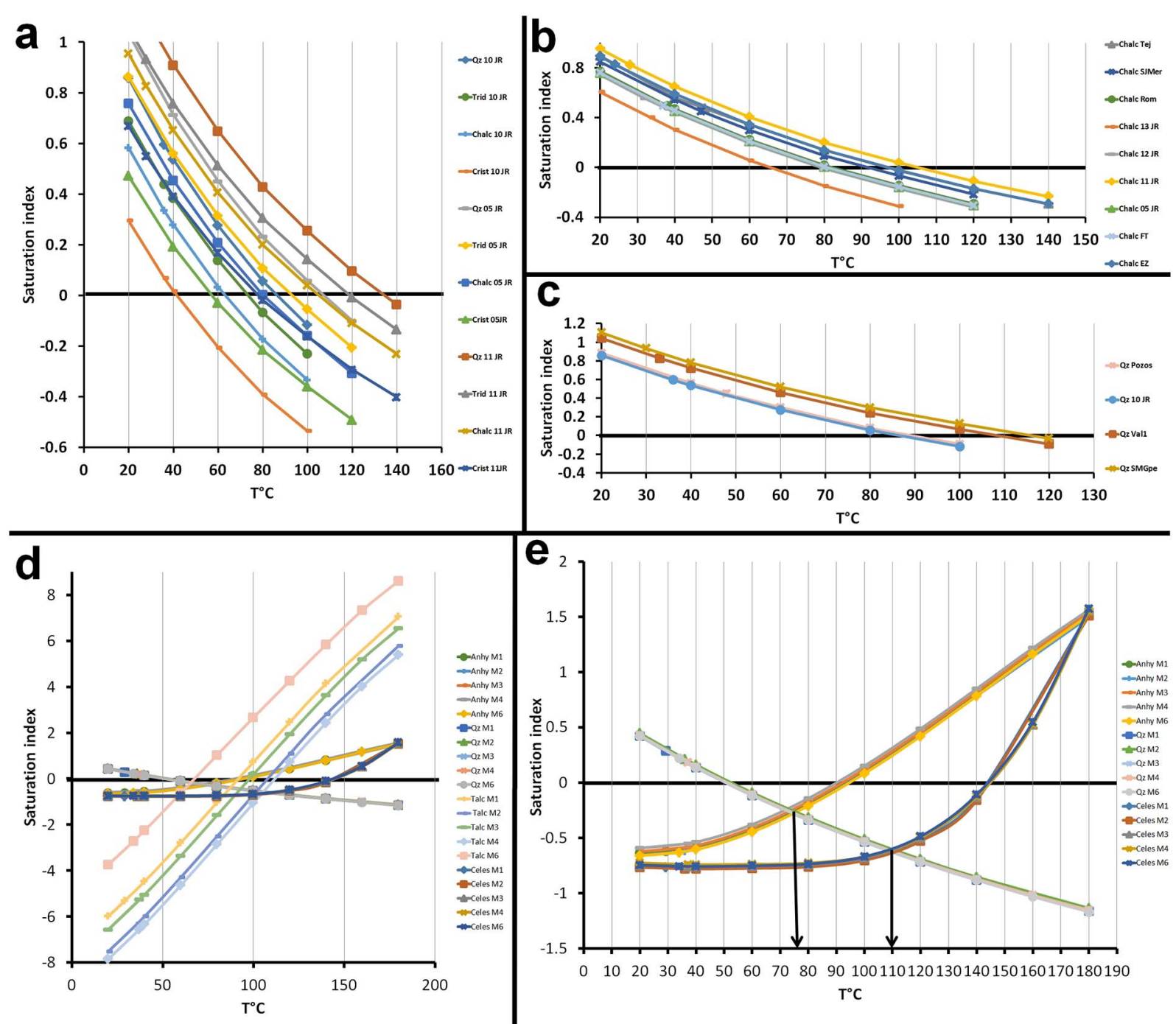

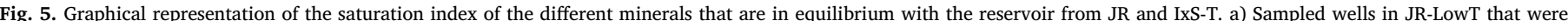

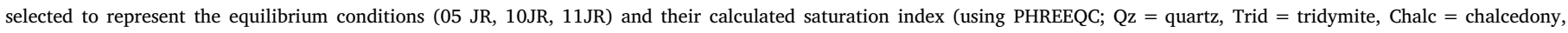

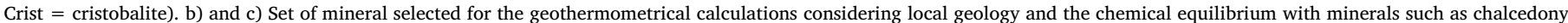

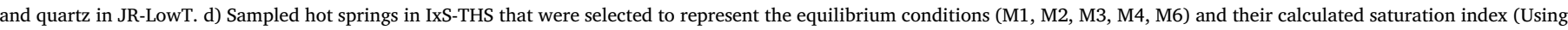

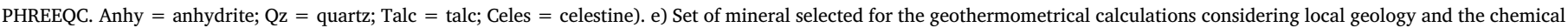
equilibrium with minerals such as anhydrite, quartz and Celestine in IxS-THS.
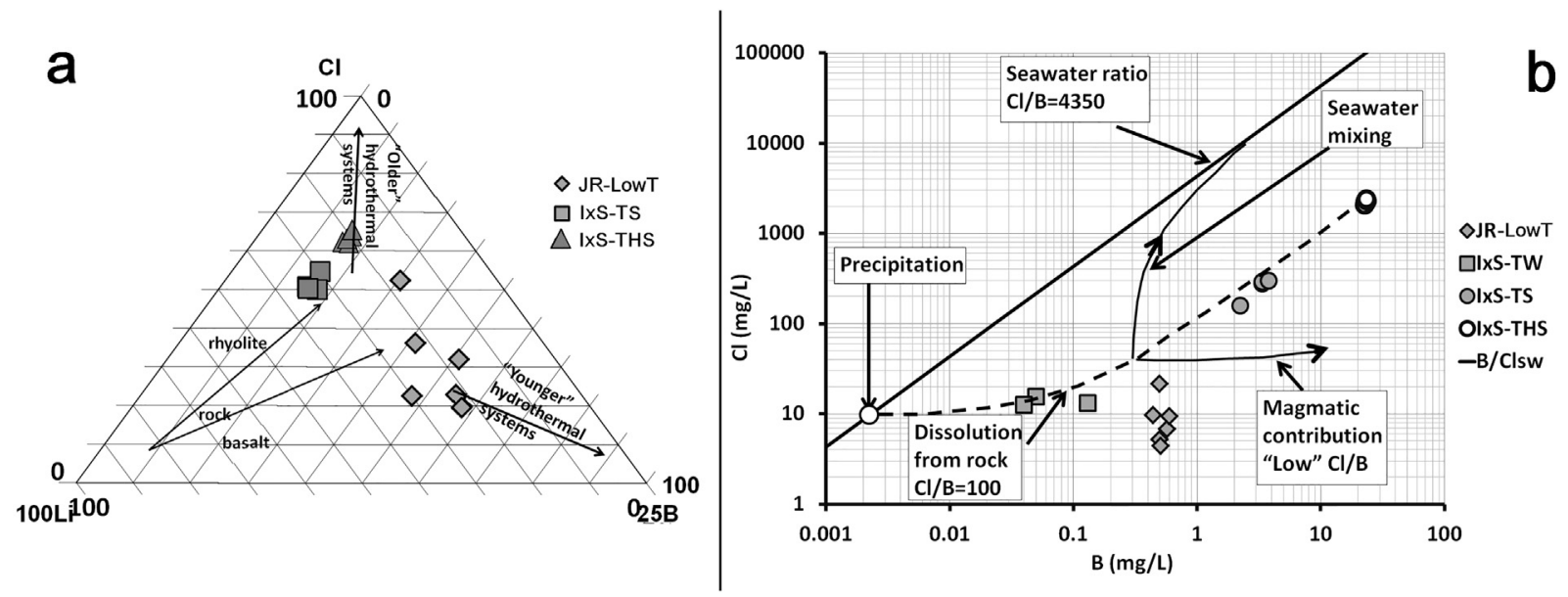

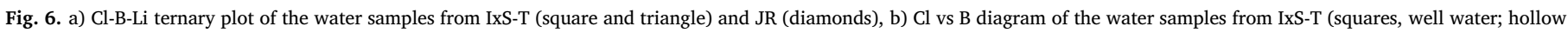
circles, thermal water; filled circles, non-thermal water) and from JR (diamonds); (B/Clsw = seawater ratio between $\mathrm{B}$ and $\mathrm{Cl}$ ). 


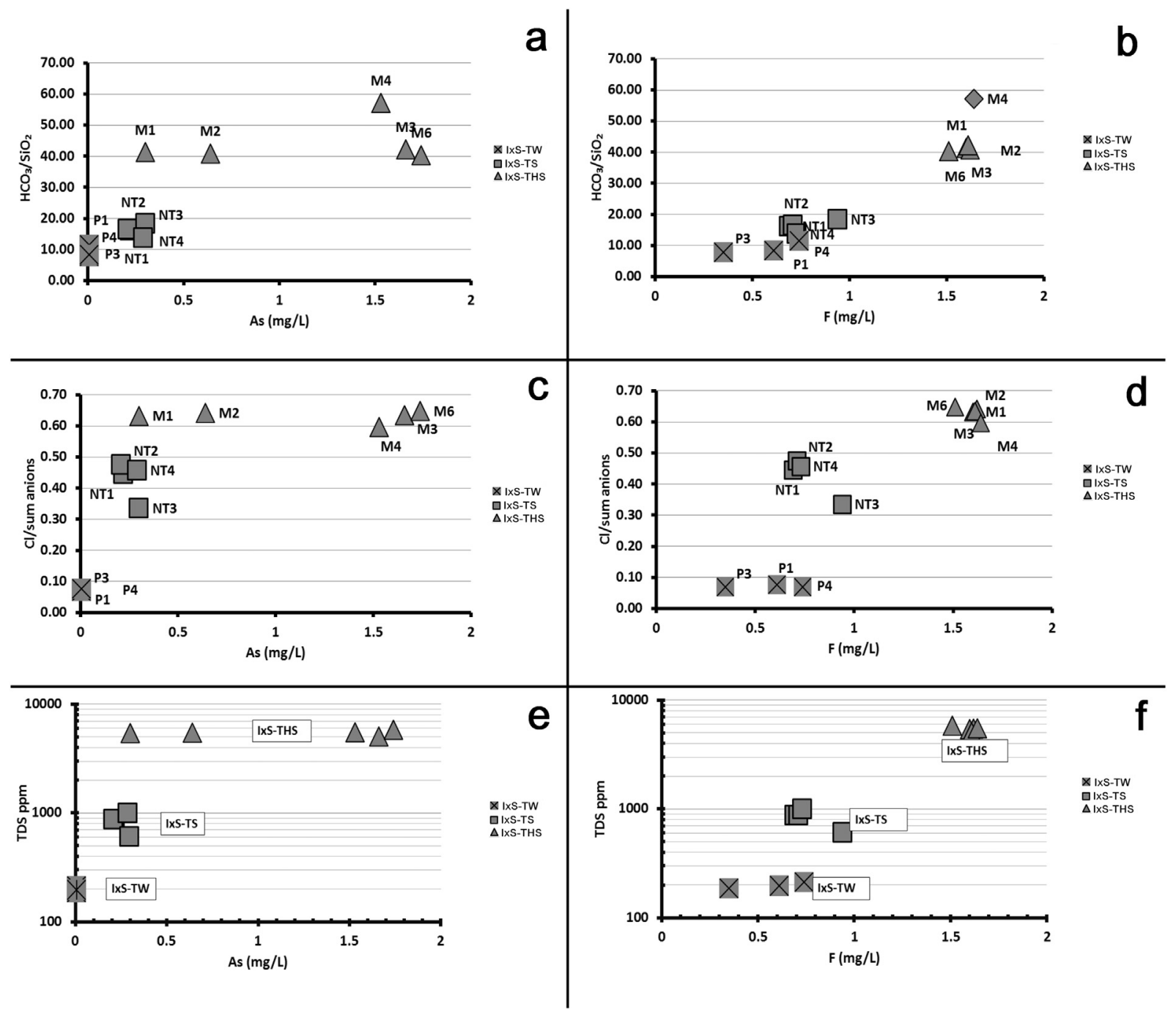

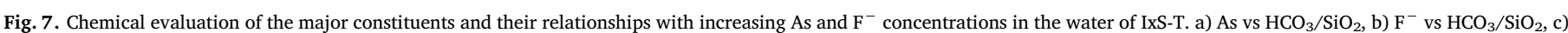
As vs $\mathrm{Cl}$ /sum anions, d) $\mathrm{F}^{-}$vs $\mathrm{Cl} /$ sum anions, e) As vs TDS, and f) $\mathrm{F}^{-}$vs TDS.

processes and water from a deep environment) it is necessary to develop an study based on groundwater flow modeling in combination with major ion chemistry considering the isotopic evaluation of ${ }^{2} \mathrm{H},{ }^{18} \mathrm{O}$, ${ }^{3} \mathrm{He},{ }^{4} \mathrm{He},{ }^{13} \mathrm{C},{ }^{14} \mathrm{C}$ or ${ }^{86} \mathrm{Sr}$ and ${ }^{87} \mathrm{Sr}$.

\section{Arsenic and fluorides}

In IxS-T, presence of $\mathrm{As}_{\text {tot }}$ and $\mathrm{F}^{-}$may be related with the chemical weathering of sedimentary rocks. As shown in Fig. $7 \mathrm{a}$ and b, the $\mathrm{HCO}_{3} /$ $\mathrm{SiO}_{2}$ relation which can discriminate between the chemical weathering of carbonates $(>10)$ and silicates $(<5)$, presents values higher than 10 (Hounslow, 1995).

In Fig. $7 \mathrm{c}$ and $\mathrm{d}$, the relationships of $\mathrm{As}_{\text {tot }}$ and $\mathrm{F}^{-}$to $\mathrm{Cl}^{-} /$sum anions can differentiate between brine-water of marine evaporite rocks $(>0.8$ and TDS $>500 \mathrm{ppm}$ ), rainwater $(>0.8$ and TDS $<100 \mathrm{ppm})$, and the chemical weathering of rocks $(<0.8)$. In these figures, the samples from thermal and non-thermal springs presented values higher than 0.1 (except in the case of wells). These values in addition to those of the TDS, which were $>500 \mathrm{ppm}$, indicate the presence of brine-water in a marine evaporite rock environment. With respect to Fig. 7e and f, the TDS concentrations allows to differentiate fresh water $(<1000 \mathrm{ppm})$, drinking water $(<500 \mathrm{ppm})$, brackish water $(>1000 \mathrm{ppm})$, salt water $(35,000 \mathrm{ppm})$, and brine $(>35,000 \mathrm{ppm})$. According to these categories, the samples of thermal water (IxS-T THS) may be classified as brackish water and the rest of the samples as fresh water (Levy et al., 1999).

The salinity levels (Fig. 7c and d), TDS content (Fig. 7e and f), and increase in temperature (Table 2) represent a common set of characteristics of geothermal water according to Mukherjee et al. (2009).

In the groundwater of $\mathrm{JR}$, presence of $\mathrm{As}_{\mathrm{tot}}$ and $\mathrm{F}^{-}$may be related to the chemical weathering of sodium silicate, probably of albite, biotite, or potassium feldspar, as well as the alteration of volcanic glass, this information has been previously reported (Morales et al., 2015; Morales-Arredondo et al., 2016a; Morales-Arredondo et al., 2016b). $\mathrm{The} \mathrm{Na} / \mathrm{Ca}$ relationship presented values $>1$, indicating that the chemical weathering of sodium silicates (similar to the plagioclase from which they originate) is occurring. In contrast, if the weathering of calcium silicates were occurring, the $\mathrm{Na}$ /Ca relationship would present very low values. Also, ion exchange processes could result in high $\mathrm{As}_{\text {tot }}$ and $\mathrm{F}^{-}$contents, as deduced from Fig. $8 \mathrm{~b}$ and c. In Fig. $8 \mathrm{~b}, \mathrm{Cl}^{-}$was subtracted from $\mathrm{Na}^{+}$, and any remaining sodium would likely be due to the chemical weathering of albite or ion exchange. Also, $\mathrm{Cl}^{-}$was subtracted from $\mathrm{K}^{+}$, wherein $\mathrm{K}^{+}$likely originates from the chemical weathering of biotite or potassium feldspar. In Fig. 8c, the (Na + K-Cl)/ $\mathrm{SiO}_{2}>1$ relationship suggests that cation exchange is the main source of $\mathrm{Na}^{+}$(if the $\mathrm{Ca}^{2+}$ content is low). Also, the $\mathrm{F}^{-}$content increases with temperature as has been observed at other sites like San Luis Potosí and Los Altos de Jalisco (Carrillo and Armienta, 1989; Hurtado-Jimenez and 

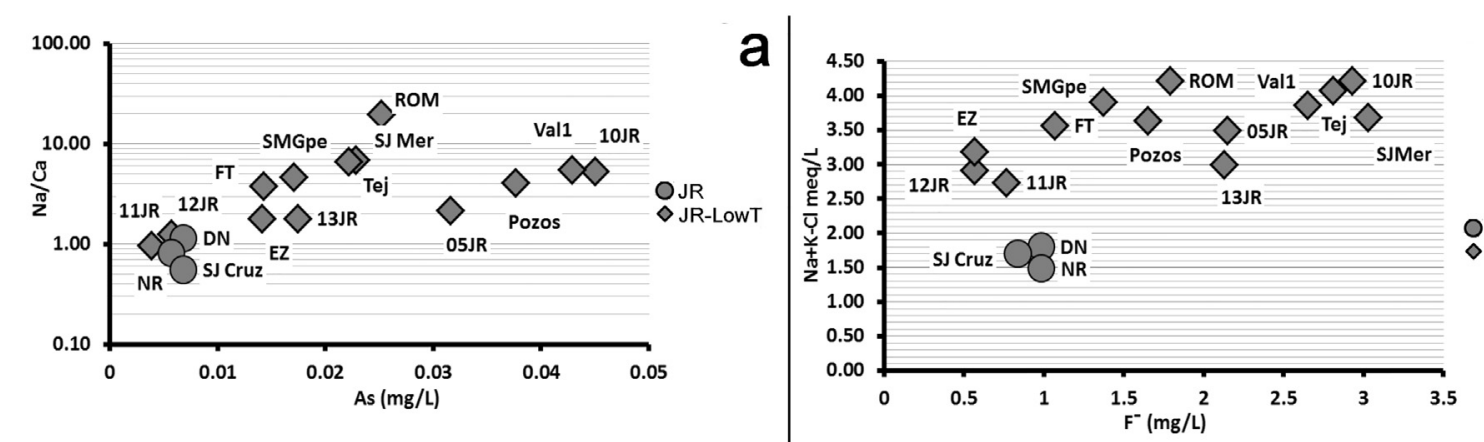

b
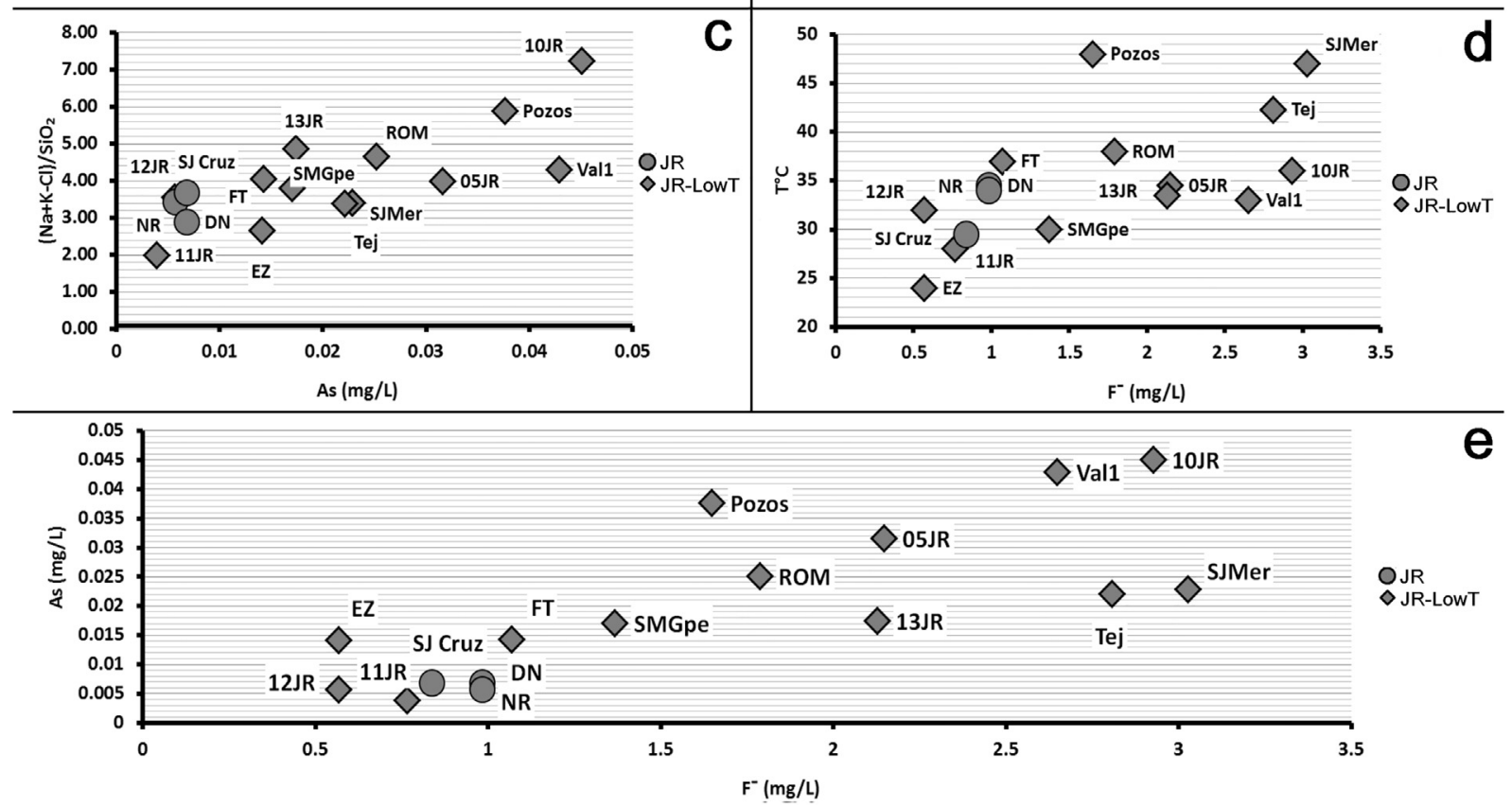

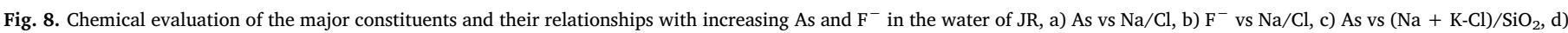
$\mathrm{F}^{-}$vs $(\mathrm{Na}+\mathrm{K}-\mathrm{Cl}) / \mathrm{SiO}_{2}$, and e) $\mathrm{F}^{-}$vs As.

Gardea-Torresdey, 2005). This process may be related to silicates alteration and volcanic glass dissolution. However, this increase was not observed above $30^{\circ} \mathrm{C}$, more research is needed on specific geochemical processes and kinetics to explain this behavior (Fig. 8d). In addition, $\mathrm{As}_{\text {tot }} \mathrm{Vs} \mathrm{F}^{-}$show an increasing concentration trend (Fig. 8e) probably indicating the same source.

\section{Water potability}

In the majority of sites evaluated in IxS-T, the concentrations of As exceeded up to 10 times the permissible limit established in NOM-127 (As $=0.025 \mathrm{mg} / \mathrm{L}$ ), whereas the $\mathrm{F}^{-}$content only presented values above the established limit in thermal springs $\left(\mathrm{F}^{-}=1.5 \mathrm{mg} / \mathrm{L}\right)$. In $\mathrm{JR}$, several wells of potable water presented $\mathrm{As}_{\text {tot }}$ and $\mathrm{F}^{-}$values up to double the permissible limits in NOM-127, thereby presenting a risk to the local population, especially if water is consumed or used for daily activities such as cooking or watering edible crops. In both regions, the presence of $\mathrm{As}_{\text {tot }}$ and $\mathrm{F}^{-}$is associated with geothermal water (Morales et al., 2015; Rodríguez et al., 2016; Martínez-Florentino, 2015) because as water temperature rises; the $\mathrm{As}_{\text {tot }}$ and $\mathrm{F}^{-}$concentrations also increase (Tables 2 and 3). In the evaluated sites (rural communities) the problem has not been remediated. Water treatment by osmosis (and other treatments) is mainly used in cities. Most rural communities with $\mathrm{As}_{\text {tot }}$ and $\mathrm{F}^{-}$presence lack of water treatment systems. Only in the state of Chihuahua (northern Mexico) use of osmosis systems in rural areas is widespread.

To evaluate whether the populations of both sites are experiencing negative effects resulting from exposure to As and $\mathrm{F}^{-}$and to determine the latent risk, an epidemiological study is required (ASTDR, 2008).

\section{Conclusions}

The IxS-T and the JR regions display characteristics of low-temperature thermal systems according to results obtained with geothermometers and the saturation indexes calculated at different temperatures. In both regions, an interaction is occurring between metamorphic sedimentary rocks and volcanic material. However, water in IxS-T has mainly interacted with sedimentary rocks (carbonate), while the aquifer matrix in JR corresponds to volcanic rocks. Based on the chemistry of sampled water, the dominant hydrogeochemical processes of IxS-T are associated with the dissolution of sedimentary rocks (e.g., limestones and dolomites) or minerals related with evaporite deposits, leading to the liberation of high concentrations of mainly $\mathrm{Na}^{+}, \mathrm{Ca}^{2+}, \mathrm{Cl}^{-}$, As, and $\mathrm{F}^{-}$. The salinity of these samples could be due to the hydrogeochemical evolution of water occurring at great depths, which is affected by the geothermal environment. The dominant hydrogeochemical processes in JR were associated with the dissolution of silicates present in volcanic rocks and with cation exchange processes that are accelerated by rising temperature and thereby lead to an increase in the $\mathrm{Na}^{+}, \mathrm{HCO}_{3}^{-}$As, and $\mathrm{F}^{-}$contents.

To estimate the temperature of geothermal water in high salinity sedimentary aquifers the $\mathrm{K}^{2} / \mathrm{Mg}$ and $\mathrm{Na}-\mathrm{K}-\mathrm{Ca}$ with $\mathrm{Mg}$ correction geothermometers are adequate. On the other hand, to estimate the temperature of geothermal water from altered silicates felsic volcanic 
reservoirs, chalcedony and quartz geothermometers are adequate.

The presence of $\mathrm{As}_{\text {tot }}$ and $\mathrm{F}^{-}$in the groundwater of JR and IxS-T can be associated with particular hydrogeochemical characteristics and could result from the dissolution of encased rock and the migration of hydrothermal flows through fault and fracture systems, which contain high quantities of these elements, geochemical comparison between $\mathrm{Cl}$, $\mathrm{B}$ and $\mathrm{Li}$ helps to identify mixing processes in IxS-T, while these processes are not clear in JR. The rocks of each region also present particular mineralogical characteristics, because in JR volcanic rocks dominate and in IxS-T sedimentary rocks are the most important, wherein $\mathrm{As}_{\text {tot }}$ and $\mathrm{F}^{-}$are present in mica and feldspar (JR) and in carbonate, and evaporite minerals (IxS-T). No chemical evidence of a magmatic contribution was found at any of the studied zones. To evaluate the behavior of As and F in IxS-T it is necessary to consider TDS, $\mathrm{Cl}^{-}, \mathrm{HCO}_{3}{ }^{-}$ and $\mathrm{SiO}_{2}$ concentrations; while for JR, elements like $\mathrm{Na}$ and $\mathrm{HCO}_{3}-$ related with the alteration of sodium silicates should be considered.

In the IxS-T water samples, the concentrations of As surpassed up to 10 times the permissible limits of NOM-127. In JR, wells of potable water with hydrothermal characteristics presented up to double the permissible limit of $\mathrm{As}_{\text {tot }}$. These high concentrations constitute a risk for local populations.

\section{Acknowledgments}

The study carried out in the IxS-T region was financed by Universidad Autónoma del Estado de México (clave 3716/2014). The authors would like to thank CONACyT for its support and the scholarships provided to students A. K. Martínez-Florentino and I. Morales. The authors are also thankful for the support of O. Cruz, N. Ceniceros, and A. Aguayo from the Laboratorio de Química Analítica of the Instituto de Geofísica, UNAM, and the Laboratorio de Geoquímica of the Juriquilla Campus, UNAM, in performing the chemical analyses, thankful for help in field sampling to I. Flores-Ocampo and R. Flores-Vargas.

\section{References}

APHA, AWWA and WWF, 2005. Standard Methods for the Examination of Water and Wastewater. American Public Health Association, the American Water Works Association, Association Water Environment Federation, Washington, D. C.

Appelo, C.A.J., Postma, D., 2005. Geochemistry, Groundwater and Pollution, 2nd ed. A.A. Balkema Publishers, Rotterdam, The Netherlands (647 pp.).

Armienta, M.A., Segovia, N., 2008. Arsenic and fluoride in the groundwater of Mexico. Environ. Geochem. Health 30, 345-353.

Arnorsson, S., 1975. Application of the silica geothermometer in low temperature area in Iceland. Am. J. Sci. 275, 763-784.

Arnórsson, S., Andrésdóttir, A., 1995. Processes controlling the distribution of boron and chlorine in natural waters in Iceland. Geochim. Cosmochim. Acta 59, 4125-4146.

ASTDR, 2008. Public Health Assessment Guidance Manual. Agency for Toxic Substances and Disease Registry. www.astdr.cdc.gov/HAC/PHAmanual/index.html\#foreword.

Ban, M., Hasenaka, T., Delgado-Granados, H., Takaoka, N., 1992. K-Ar ages of lavas from shield volcanoes in the Michoacan-Guanajuato volcanic field, Mexico. Geofis. Int. 31 (4), 467-473.

Betancourt-Lineares, A., Irigoyen-Camacho, M.E., Mejía-González, A.M., Zepeda-Zepeda, M., Sánchez-Pérez, L., 2013. Prevalencia de fluorosis dental en localidades mexicanas ubicadas en 27 estados y el D.F. a seis años de la publicación de la Norma Oficial para la fluoruración de la sal. Rev. Investig. Clin. 65 (3), 237-247.

Campa, M.F., 1978. La Evolución Tectónica de Tierra Caliente, Guerrero IV Conv. Geol. Nal. Mems Tomo XXXIX No. 2.

Capaccioni, B., Didero, M., Paletta, C., Didero, L., 2005. Saline intrusion and refreshening in a multilayer coastal aquifer in the Catania Plain (Sicily, Southern Italy): dynamics of degradation processes according to the hydrochemical characteristics of groundwater. J. Hydrol. 307, 1-16.

Carpenter, A.B., 1978. Origin and chemical evolution of brines in sedimentary basins Oklahoma. Geol. Surv. Circ 79, 78-88.

Carrillo, J.J., Armienta, M.A., 1989. Diferenciación de la contaminación inorgánica en las aguas subterráneas del Valle de la Ciudad de San Luis Potosí, SLP, Mexico. Geofis. Int. 28 (4), 763-783.

Chadha, D.K., 1999. A proposed new diagram for geochemical classification of natural waters and interpretation of chemical data. Hydrogeol. J. 7 (5), 431-439.

D'Amore, F., Scandiffio, G., Panichi, C., 1983. Some observations on the chemical classification of ground waters. Geothermics 12, 1-14.

Drever, J.I., Hurcomb, D.R., 1986. Neutralization of atmospheric acidity by chemical weathering in an alpine drainage basin in the North Cascades Mountains. Geology 14, 221-224.

Esteller, M.V., Domínguez-Mariani, E., Garrido, S.E., Aviles, M., 2015. Groundwater pollution by arsenic and other toxic elements in an abandoned silver mine, Mexico. Environ. Earth Sci. 74, 2893-2906.

Fournier, R.O., 1977. Chemical geothermometers and mixing models for geothermal systems. Geothermics 5, 41-50.

Fournier, R.O., Potter II, R.W., 1979. Magnesium correction to Na-K-Ca geothermometer. Geochim. Cosmochim. Acta 43, 1543-1550.

García-Palomo, A., Macias, J.L., Arce, J.L., Capra, L., Garduño, V.H., Espíndola, J.M., 2002. Geology of Nevado de Toluca Volcano and Surrounding Áreas, Central Mexico: Boulder, Colorado, Geological Society of America Map and Cart Series MCH089. (26 pp.).

Giggenbach, 1986. The Use of Gas Chemistry in Delineating the Origin of Fluids Discharges Over the Taupo Volcanic Zone: A Review. International Volcanological Congress, Hamilton, New Zealand.

Giggenbach, W.F., Glover, R.B., 1992. Tectonic regime and major processes governing the chemistry of water and gas discharges from the Rotorua Geothermal Field, New Zealand. Geothermics 21 (1-2), 121-140.

Giggenbach, W.F., Gonfiantini, R., Jangi, B.L., Truesdell, A.H., 1983. Isotopic and chemical composition of Parbati Valley geothermal discharges, northwest Himalaya, India. Geothermics 12, 199-222.

Goldschmidt, V.M., Peters, C., 1932. Geochemie des Bors. I. Nachr. Ges. Wiss. Mathphysik Kl (Gottingen). pp. 402-407.

Hanor, J.S., 1994. Origins of saline fluids in sedimentary basins. In: Parnell, J. (Ed.), Geofluids: Origin, Migration and Evolution of Fluids in Sedimentary Basins. Geological Society of London, pp. 151-174.

Hounslow, A.W., 1995. Water Quality Data: Analysis and Interpretation. CRC Press, Boca Raton, Florida, pp. 397

Hurtado-Jimenez, R.J., Gardea-Torresdey, 2005. Estimación de la exposición a fluoruros en los Altos Jalisco, Mexico. Salud Publica Mex. 47, 58-63.

Jalali, M., 2005. Major ion chemistry of groundwaters in the Bahar area, Hamadan, western Iran. J. Environ, Geol, 47, 763-772.

Karingithi, C.W., 2009. Chemical Geothermometers for geothermal exploration. In: Presented at Short Course IV on Exploration for Geothermal Resources, Organized by UNU-GTP, KenGen and GDC, at Lake, Naivasha, Kenya, November, 1-22.

Kharaka, Y.K., Hanor, J.S., 2007. Deep Fluids in the Continents: I. Sedimentary Basins. 5. Elsevier, pp. 1-48.

Larsen, D., Swihartb, G., Xiaoc, Y., 2001. Hydrochemistry and isotope composition of springs in the Tecopa basin, southeastern California, USA. Chem. Geol. 179, 17-35.

Levinson, A.A., 1980. Introduction to Exploration Geochemistry, 2nd ed. Applied Publishing Ltd., Wilmette, Illinois (924 pp.).

Levy, D.B., Schramke, J.A., Esposito, K.J., Erickson, T.A., More, J.C., 1999. The shallow groundwater chemistry of arsenic, fluorine, and major elements: Eastern Owens Lake, California. Appl. Geochem. 14, 53-65.

Magaña, B.M.I., 1999. Geochemical interpretation of thermal fluid discharge from wells and springs in the Berlín geothermal field, El Salvador. Report 7, 165-191.

Martínez-Florentino, T.A.K., 2015. Caracterización hidrogeoquímica del Sistema de manantiales termales de Ixtapan de la Sal - Tonatico, Estado de México (Tesis de Maestría). Universidad Autónoma del Estado de México, Facultad de Ingeniería.

Mnjokava, T.T., 2007. Interpretation of exploration geochemical data for geothermal fluids from the geothermal field of Rungwe volcanic area, SW-Tanzania. Report 14, 303-332.

Morales, I., Villanueva-Estrada, R.E., Rodríguez, R., Armienta, M.A., 2015. Geological, hydrogeological, and geothermal factors associated to the origin of arsenic, fluoride, and groundwater temperature in a volcanic environment "El Bajío Guanajuatense" Mexico. Environ. Earth Sci. 74, 5403-5415.

Morales-Arredondo, I., Rodríguez, R., Armienta, M.A., Villanueva-Estrada, R.E., 2016a. A low-temperature geothermal system in central Mexico: hydrogeochemistry and potential heat source. Geochem. J. 50 (3), 211-225.

Morales-Arredondo, I., Rodríguez, R., Armienta, M.A., Villanueva-Estrada, R.E., 2016b. The origin of groundwater arsenic and fluorine in a volcanic sedimentary basin in central Mexico: a hydrochemistry hypothesis. Hydrogeol. J. 24 (4), 1029-1044. http://dx.doi.org/10.1007/s10040-015-1357-8.

Mukherjee, A., Fyar, E.A., O'Shea, B.M., 2009. Major occurrences of elevated arsenic in groundwater and other natural waters. In: Henke, Kevin (Ed.), Arsenic:

Environmental Chemistry, Health Threats and Waste Treatment. John Wiley \& Sons, Ltd., pp. 300-350.

Nicholson, K., 1993. Geothermal Fluids. Springer Verlag, Berlin (XVIII-264 pp.).

NOM-127-SSA1-1994. Norma Oficial Mexicana "Salud ambiental, agua para uso y consumo humano-límites permisibles de calidad y tratamientos a que debe someterse el aguapara su potabilizacion" (MODIFICADA 2000). (7 pp.).

Peacock, S.M., Hervig, R.L., 1999. Boron isotopic composition of subduction-related metamorphic rocks. Chem. Geol. 160, 281-290.

Peters, S.C., Blum, J.D., 2003. The source and transport of arsenic in a bedrock aquifer, New Hampshire, USA. Appl. Geochem. 18, 1773-1787.

Ravenscroft, P., McArthur, J.M., 2004. Mechanisms of regional enrichment of groundwater by boron: the examples of Bangladesh and Michigan, USA. Appl. Geochem. 19, 1413-1430.

Reed, M., Spycher, N., 1984. Calculation of $\mathrm{pH}$ and mineral equilibria in hydrothermal waters with application to geothermometry and studies of boiling and dilution. Geochim. Cosmochim. Acta 48 (7), 1479-1492.

Reyes Reyes, N.A., 1998. Informe de la carta Geológico-Minera y Geoquímica Mineral de Pozos, F14-C45, Escala 1:50,000. Consejo de Recursos Minerales, Estado de Guanajuato, pp. 42.

Rodríguez, R., Morales, I., Armienta, A., Villanueva, R., Segovia, N., 2015. Geothermal systems of low temperature in Mexican highlands: alternative uses and associated risks. Procedia Environ Sci 25, 214-219.

Rodríguez, R., Morales-Arredondo, I., Rodríguez, I., 2016. Geological differentiation of 
groundwater threshold concentrations of arsenic, vanadium and fluorine in El Bajio Guanajuatense, Mexico. Geofis. Int. 55, 5-15.

Russak, A., Sivan, O., 2010. Hydrogeochemical tool to identify salinization or freshening of coastal aquifers determined from combined field work, experiments, and modeling. Environ. Sci. Technol. 44, 4096-4102.

Smedley, P.L., Kinniburgh, D.G., 2002. A review of the source, behavior and distribution of arsenic in natural waters. Appl. Geochem. 517-568.

Spivack, A.J., Palmer, M.R., Edmond, J.M., 1987. The sedimentary cycle of the boron isotopes. Geochim. Cosmochim. Acta 51, 1939-1949.
Stueber, A.M., Walter, L.M., 1991. Origin and chemical evolution of formation waters from Silurian-Devonian strata in the Illinois basin, USA. Geochim. Cosmochim. Acta 55, 309-325.

Tóth, J., 1999. Groundwater as a geologic agent: an overview of the causes, processes, and manifestations. Hydrogeol. J. 7 (1), 1-14.

Williams, L.B., Hervig, R.L., Hutcheon, I., 2001. Boron isotope geochemistry during diagenesis. Part II. Applications to organic-rich sediments. Geochim. Cosmochim. Acta 65 (11), 1783-1794. 